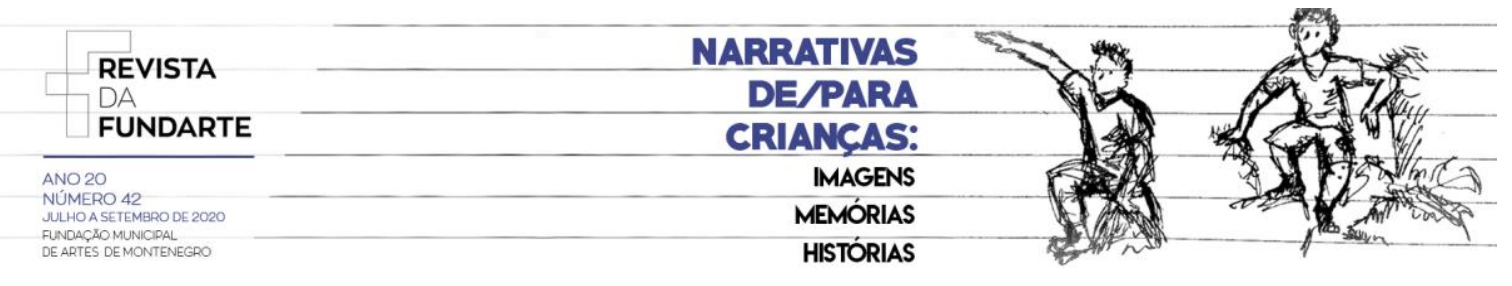

NA TEIA DE ANANSE: PERFORMANCES DE CONTAÇÃO DE HISTÓRIAS AFRO-BRASILEIRAS COM CRIANÇAS

Sonaly Torres Silva

DOI: $10.19179 / 2319-0868.801$

SILVA, Sonaly Torres. Na teia de Ananse: performances de contação de histórias afro-brasileiras com crianças. Revista da FUNDARTE. Montenegro, p.01-23, ano 23, o 42, julho/setembro de 2020. Disponível em: http://.seer.fundarte.rs.gov.br/index.php/RevistadaFundarte/index $>30$ de setembro de 2020 


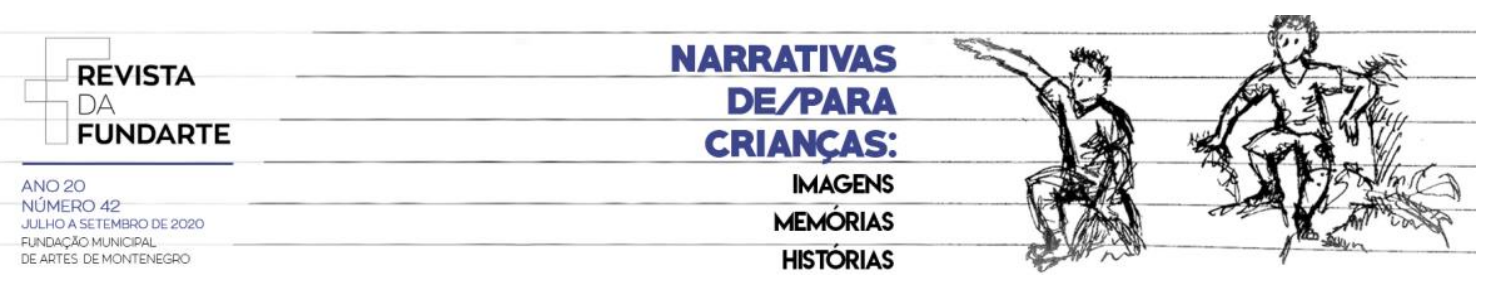

\title{
NA TEIA DE ANANSE: PERFORMANCES DE CONTAÇÃO DE HISTÓRIAS AFRO-BRASILEIRAS COM CRIANÇAS
}

Sonaly Torres Silva ${ }^{1}$

\begin{abstract}
Resumo: Esse artigo apresenta reflexões acerca da pesquisa $\mathrm{Na}$ Teia de Ananse: performances de contação de histórias com crianças na escola, em desenvolvimento no âmbito do Programa de Pósgraduação em Performances Culturais, em nível de doutorado. Tem como objetivo compartilhar experiências de uma pesquisa performativa, realizada em duas escolas públicas de Ensino Fundamental, no interior de Minas Gerais - Brasil, cujo foco é contação de histórias com crianças. Nesse processo busco compreender como performances narrativas que integram contos africanos, cultura afro-brasileira e narrativas das crianças podem propiciar emergência de resistências com protagonismo da infância.
\end{abstract}

Palavras-chave: Contação de histórias; Performances; Protagonismo infantil.

\section{IN ANANSE'S WEB: AFRO-BRAZILIAN STORRYTELLING PERFORMANCES WITH CHILDREN}

\begin{abstract}
This article presents reflections about the performative research In Ananse's web: storytelling performances with children at school, under development in the scope of the Postgraduate Program in Cultural Performances, at a doctorade degree. It aims to share experiences of a performative research, realized in two public elementary schools, in Minas Gerais - Brazil, whose focus is storytelling with children. In this process, I wish to understand how that narrative performances that integrate African tales, Afro-Brazilian culture and children's narratives can provide an emergence of resistances with the protagonism of childhood.
\end{abstract}

Keywords: Storytelling; Performances; Children's protagonism.

\section{DANS LES TOILES DE L'ANANSE : PERFORMANCE DE NARRATION DES HISTOIRES AFRO-BRESILIEN AVEC LES ENFANTS}

Résumé: Cet article présente des réflexions concernant la recherche $\mathrm{Na}$ Teia de Ananse (Dans la toile d'Ananse) : performances de narration des contes avec des enfants à l'école, en développement dans le cadre du programme de troisième cycle en Performances culturelles, au niveau doctoral. II vise à partager expériences d'une recherche performative, menée dans deux écoles primaires publiques, à Minas Gerais - Brésil, dont le thème est la narration des contes avec les enfants. Dans ce processus, je cherche à comprendre comment les performances narratives qui intègrent les contes africains, la culture afro-brésilienne et les récits des enfants peuvent favoriser l'émergence des résistances avec le protagonisme de l'enfance.

Mots-clés: Narration; Les performances; Protagonisme de l'enfant.

\footnotetext{
${ }^{1}$ Contadora de Histórias, Professora e Terapeuta. Doutoranda em Performances Culturais, Graduada em Pedagogia, Pós-graduada em Psicopedagogia e Mestre em Psicologia. Desenvolve estudos e práticas junto a crianças desde 1988. Atuou na Educação Infantil, Ensino Fundamental e no Ensino Superior em cursos de graduação em Pedagogia e pós-graduação em Psicopedagogia. Atualmente os estudos, bem como os encontros com as crianças, acontecem a partir das experiências da pesquisa na Teia de Ananse, sobre contação de histórias e narração.
}

SILVA, Sonaly Torres. Na teia de Ananse: performances de contação de histórias afro-brasileiras com crianças. Revista da FUNDARTE. Montenegro, p.01-23, ano 23, № 42, julho/setembro de 2020. Disponível em: http://.seer.fundarte.rs.gov.br/index.php/RevistadaFundarte/index> 30 de setembro de 2020 


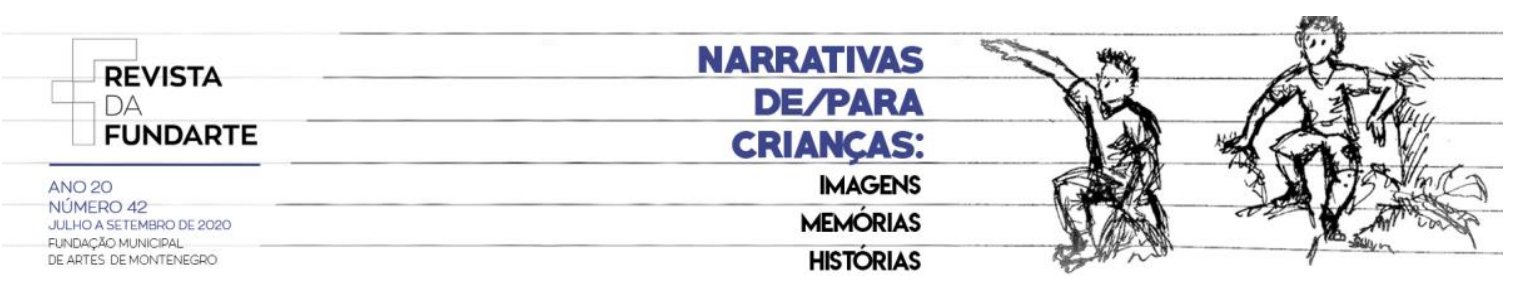

Na Teia de Ananse: uma breve apresentação

No início dos tempos, não havia histórias na Terra, todas pertenciam a Nyame, o Deus do Céu. Ananse, o homem aranha africano, desejava contar histórias para seu povo. À vista disso, teceu um fio de prata do céu até a Terra e por ele subiu. Quando Nyame soube que Ananse queria comprar as Suas histórias colocou um preço muito alto, com grandes desafios. Ananse conseguiu vencê-los. Nyame concedeu-lhe o baú de histórias e o homem aranha desceu por sua teia trazendo as histórias do céu para seu povo. Mas, quando o baú foi aberto, elas se espalharam pelos quatro cantos da Terra. Desde então, as histórias fluem numa teia viva de infinitas conexões, que entrelaçam diferentes experiências, compartilhadas através de performances que integram corpos, contatos, gestos, sons, palavras.

Esse é um resumo do conto Ananse, que inspira este trabalho. Adwoa Badoe, médica e contadora de histórias nascida em Gana, juntamente com Baba Wagué Diakité, artista plástico, escritor e contador de histórias nascido no Mali, escreveram a coletânea Histórias de Ananse (BADOE;DIAKITÉ, 2006). Nessa obra eles afirmam que essas histórias foram/são transmitidas de boca em boca e integram a tradição oral do povo Axânti, habitante da região costeira da África Ocidental, que ocupou também a região atualmente conhecida como Gana. Ananse é uma aranha, mas é um homem. Personagem popular nessa região, ele é considerado um herói, intermediário entre os seres divinos e o mundo dos homens: é o guardião das histórias.

De acordo com Hampaté Bâ, escritor, etnólogo e mestre de culturas tradicionais africanas, nascido em Mali no ano de 1900, a palavra tem origem divina e, através da tradição oral, essa origem revela-se ao entendimento humano. O ser humano, por sua vez, está ligado à palavra que profere, "a própria coesão da sociedade repousa no valor e no respeito pela palavra" (HAMPATÉ BÂ, 1980, p.

SILVA, Sonaly Torres. Na teia de Ananse: performances de contação de histórias afro-brasileiras com crianças. Revista da FUNDARTE. Montenegro, p.01-23, ano 23, № 42, julho/setembro de 2020. Disponível em: http://.seer.fundarte.rs.gov.br/index.php/RevistadaFundarte/index> 30 de setembro de 2020 


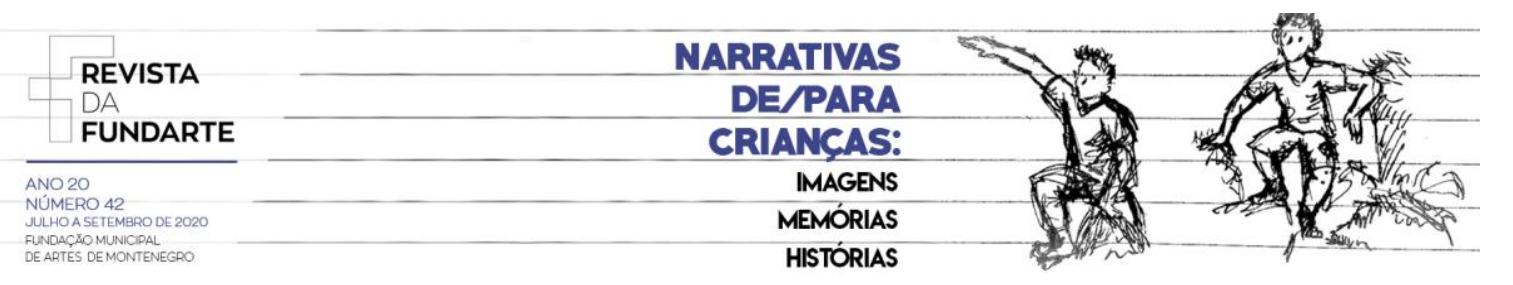

168). Dessa maneira, nas histórias, tudo está integrado: o espiritual, o material, a ciência, a arte, o conhecimento, o divertimento. A partir dessa abordagem, observo que as histórias expressam os diversos aspectos da vida, integram experiências concretas, culturas, espiritualidade, simbologias, saberes.

"Na Teia de Ananse"2 é o título da pesquisa na qual realizo performances de contação de histórias junto a crianças em escolas públicas de Minas Gerais, tendo como objetivos: 1. propiciar o encontro entre contos africanos, expressões de cultura afro-brasileira e narrativas das crianças; 2. contribuir para promover maior conhecimento e respeito pelo patrimônio diversificado de culturas africanas e afrobrasileiras; 3. observar como performances de contação de histórias podem contribuir para a emergência do protagonismo de crianças em contextos escolares.

Em minha trajetória, além de atuar como pesquisadora, sou contadora de histórias e professora. Estudo e desenvolvo práticas junto a crianças desde 1988. Os estudos, as reflexões e os diálogos acerca da infância e contação de histórias perpassam as minhas experiências como professora na Educação Básica e no Ensino Superior.

A partir dessas experiências, foi possível perceber que histórias de tradição europeia são mais presentes nos contextos escolares brasileiros que aquelas de tradição africana. Diferentes estudos e autores como Silva (2011), Arena e Lopes (2013), Silva (2015) corroboram essa percepção referente à predominância da cultura de matriz europeia e à baixa frequência da presença de personagens negros em contextos escolares. Diante disso, vejo os contos africanos em conexão com expressões de culturas afro-brasileiras, como fios que se entrelaçam na teia dessa pesquisa, pois, além de serem pujantes nas experiências de performances da pesquisadora, podem contribuir para a valorização da diversidade cultural, diante dos "Perigos de uma História Única" (ADICHIE, 2009). Concordo com a escritora Chimamanda Adichie quando afirma que é impossível nos relacionarmos com

\footnotetext{
2 A pesquisa Na Teia de Ananse conta com apoio da Coordenação de Aperfeiçoamento de Pessoal de Nível Superior - Brasil (CAPES) - Código de Financiamento 001.
}

SILVA, Sonaly Torres. Na teia de Ananse: performances de contação de histórias afro-brasileiras com crianças. Revista da FUNDARTE. Montenegro, p.01-23, ano 23, № 42, julho/setembro de 2020. Disponível em: http://.seer.fundarte.rs.gov.br/index.php/RevistadaFundarte/index> 30 de setembro de 2020 


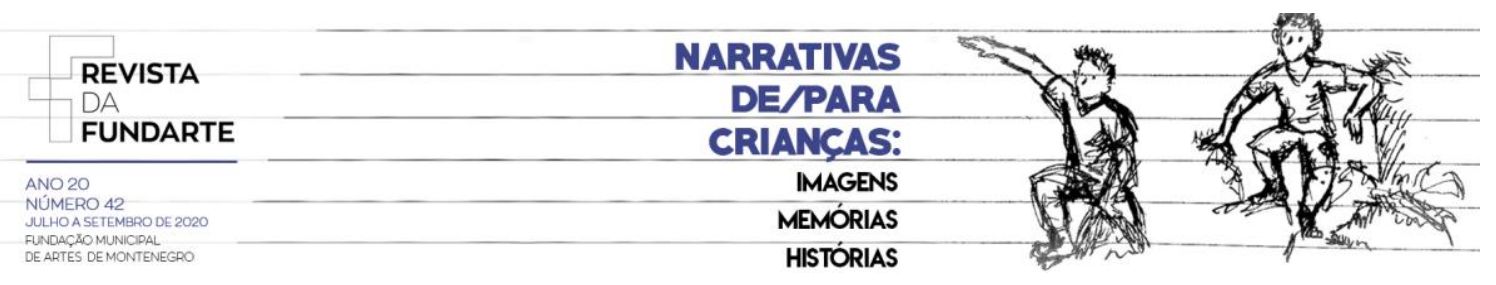

pessoas ou lugares sem compartilharmos nossas histórias. Portanto, é fundamental contar, ouvir, ler e criar muitas e diferentes histórias, o que pode contribuir para o reconhecimento de nossa humanidade compartilhada.

Nesta perspectiva, ao considerar que performances de contação de histórias que integram histórias africanas, expressões de cultura afro-brasileira e narrativas das crianças, podem produzir abertura para uma diversidade de histórias em contraponto às histórias de origem europeia que predominam em contextos educativos brasileiros, indago: como performances de contação de histórias compartilhadas entre adultos e crianças podem propiciar a emergência de novas práticas no contexto escolar e contribuir para reconhecimento de nossa humanidade compartilhada?

Ressalto que estudar o ato de contar histórias como performance é adentrar um campo complexo. Diferentes autores, dentre eles Richard Bauman (2014) e Paul Zumthor (2002), enfatizam a complexidade dessa arena conceitual interdisciplinar. Trata-se de um campo que não está claramente delineado e, portanto, o termo performance pode adquirir conotações diversas, co-existindo diferentes paradigmas conceituais. Dessa forma, estudos no campo das performances permitem uma perspectiva interdisciplinar agregadora, na qual o teatro, os rituais, as danças, os cantos e as narrativas orais podem ser contemplados de forma holística e analiticamente produtiva (HARTMANN, 2014).

Neste sentido, desenvolvo a pesquisa performativa "Na Teia de Ananse". Conforme Haseman (2015), a pesquisa performativa surge como uma estratégia de investigação dentro de um novo paradigma de pesquisa guiada-pela-prática. Pesquisadores performativos realizam pesquisas intrinsecamente empíricas que nascem a partir das performances: eles começam a praticar para ver o que surge e podem conduzir a pesquisa a partir do "entusiasmo da prática", sendo esse o ponto de partida empírico (HASEMAN, 2015, p.44). Além disso, inspirada por Zumthor (2002), penso-sinto a performance como uma experiência poética em que é imprescindível a presença do corpo, a presença ativa de um sujeito concreto que ouve, fala, sente, toca, respira... C Concordo com o autor quando afirma que para

SILVA, Sonaly Torres. Na teia de Ananse: performances de contação de histórias afro-brasileiras com crianças. Revista da FUNDARTE. Montenegro, p.01-23, ano 23, № 42, julho/setembro de 2020. Disponível em: http://.seer.fundarte.rs.gov.br/index.php/RevistadaFundarte/index> 30 de setembro de 2020 


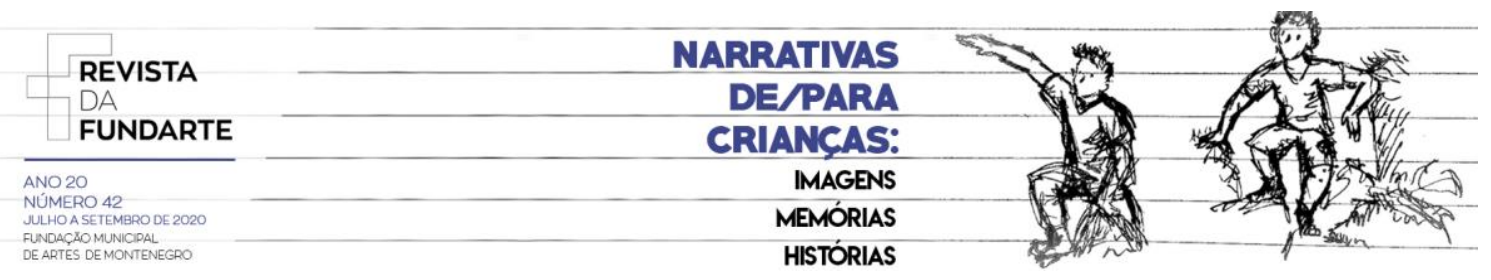

uma experiência ser poética ela depende do que suscita no corpo, do sentimento e das vibrações de prazer que provoca.

Desse modo, a Teia de Ananse foi tecida como uma experiência de pesquisa guiada pela prática em que atenção, escuta e primazia ao corpo, estão presentes em todas as atividades. Neste artigo compartilho como se deu a tessitura dessa trama $^{3}$ com objetivo de dialogar sobre o contexto e as práticas desenvolvidas. Para desenrolar o enredo desta história, puxo dois fios: (i) Onde e com quem a teia foi tecida. (ii) Como tudo começou, o que aconteceu.

\section{Onde e com quem a teia foi tecida?}

As práticas desta pesquisa foram realizadas nas cidades de Coronel Fabriciano e de Belo Oriente, localizadas no interior do estado de Minas Gerais. Essas cidades integram a Região Metropolitana do Vale do Aço (RMVA). A distância entre Coronel Fabriciano e Belo Oriente é de aproximadamente 56 quilômetros, percurso que eu fazia semanalmente no decorrer das práticas de pesquisa.

Pontuo que as cidades do Vale do Aço, são fortemente marcadas pela presença das indústrias. Assim, conforme estudo que desenvolvi no mestrado (SILVA, 2007), foi possível observar que a vida nessas cidades, em grande parte, se configura pelo ritmo das fábricas, é atravessada pelas configurações industriais.

É curioso observar como o lugar, os modos de vida, as relações que tecemos nas cidades onde vivemos, compõem o que somos e as histórias que narramos. Parafraseando o poeta Carlos Drummond de Andrade (2001): eu nasci em Coronel Fabriciano, há muitos anos eu vivo na região do Vale do Aço, noventa por cento de aço nas ruas, oitenta por cento de aço na vida, um tanto de aço nas veias, o que ás vezes (ou muitas vezes), enquadra e enrijece a forma de escrever, de narrar, de viver. Porém, nada é um bloco monolítico: também a vontade de amar, brincar, criar,

\footnotetext{
${ }^{3}$ Esse artigo é parte da pesquisa de doutorado "Na Teia de Ananse: performances de contação de histórias com crianças, na escola", desenvolvida no Programa de Pós-Graduação em Performances Culturais da Universidade Federal de Goiás.
}

SILVA, Sonaly Torres. Na teia de Ananse: performances de contação de histórias afro-brasileiras com crianças. Revista da FUNDARTE. Montenegro, p.01-23, ano 23, № 42, julho/setembro de 2020. Disponível em: http://.seer.fundarte.rs.gov.br/index.php/RevistadaFundarte/index> 30 de setembro de 2020 


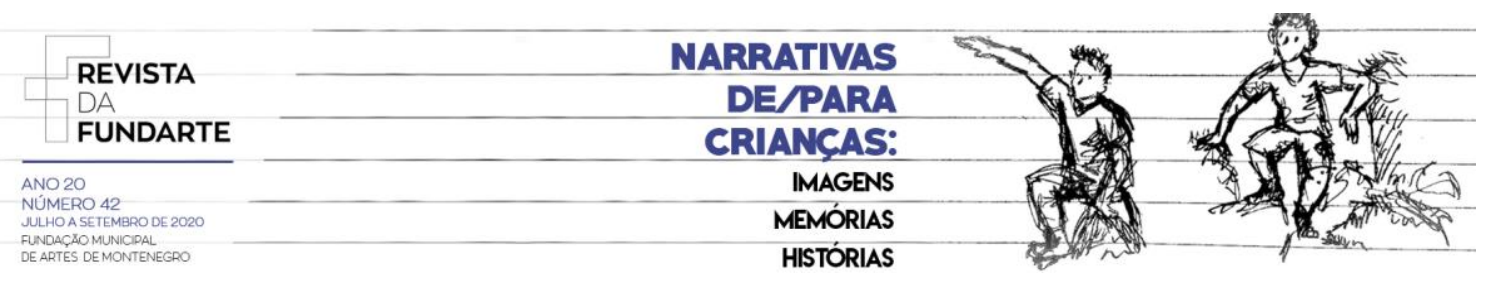

fazer arte, ouvir, inventar e compartilhar histórias, nasce e se multiplica no Vale do Aço. Foi nesse lugar que escutei as histórias de Vovô Zeca, de minha mãe Marli, da professora Lúcia; foi aqui que me encontrei com a capoeira, com Mestre Reginaldo Véio, com Mestre Moa do Katendê; aqui conheci e fui aluna do teatrólogo, diretor e dramaturgo Augusto Boal. Enfim, quase toda minha história de vida se desenvolveu na cidade de Coronel Fabriciano: aqui nasci, vivi as brincadeiras de infância, a trajetória escolar, desde a educação infantil até o ensino superior; tornei-me atriz, professora, mãe, contadora de histórias.

A cidade de Belo Oriente igualmente faz parte de minha trajetória e de minha infância. Recordo as viagens em família realizadas para visitar parentes nessa cidade: o encantamento com o lugar diferente, a convivência com outras crianças, as brincadeiras. São memórias afetivas que se intensificam e estão presentes quando retorno às escolas nestas cidades. Como afirma a contadora de histórias, professora e pesquisadora Gilka Girardello (2014): é a criança de ontem quem escolhe as histórias para a adulta de hoje narrar. Assim, a criança em mim se reapresentou diante das crianças dessas cidades, nos momentos de contação de histórias "Na Teia de Ananse", esta pesquisa performativa tricotada em escolas públicas.

Observo que, pelo fato das práticas serem realizadas em instituições escolares, o contato inicial não se deu diretamente com as crianças, mas envolveu articulação e diálogo com os adultos (gestores e educadores), para que as práticas acontecessem. Ressalto que a escola é um espaço sociocultural complexo, no qual sujeitos históricos reais se encontram em relações dinâmicas, numa perspectiva adultocêntrica, ou seja, em que os adultos buscam comandar e controlar as crianças, na tensão entre diferentes formas de exercício de poder e emergência de resistências ${ }^{4}$.

\footnotetext{
${ }^{4}$ A partir de Foucault (1977), enfatizo que resistência não significa unicamente contra-força diante do poder, mas escapadas, invenção do novo, processos de criação.
}

SILVA, Sonaly Torres. Na teia de Ananse: performances de contação de histórias afro-brasileiras com crianças. Revista da FUNDARTE. Montenegro, p.01-23, ano 23, № 42, julho/setembro de 2020. Disponível em: http://.seer.fundarte.rs.gov.br/index.php/RevistadaFundarte/index> 30 de setembro de 2020 


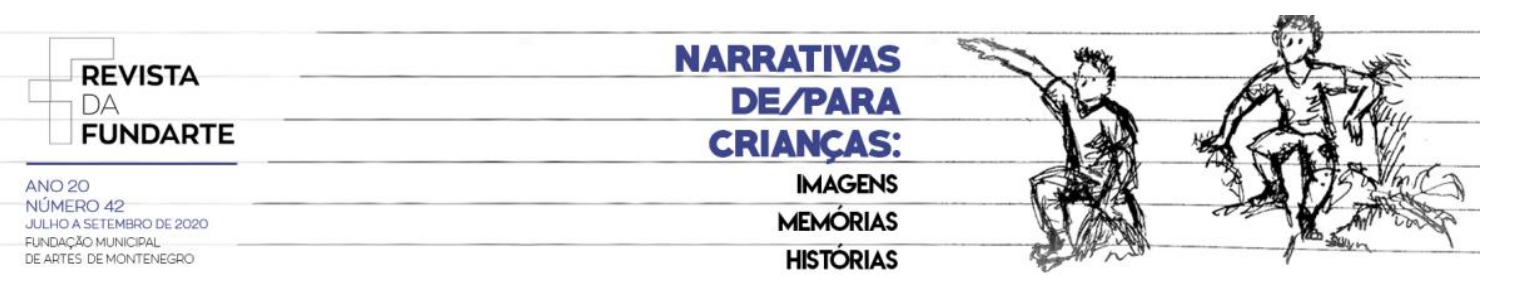

Nessa engrenagem de poder, é possível ver que as crianças estão em condições de maior subalternidade, uma vez que são forçadas a conviver e compactuar com valores e práticas prescritos pelos adultos. Nesse sentido é fundamental debater e repensar as abordagens e práticas referentes à infância, com vistas a abrir espaços para a manifestação da criança como sujeito histórico, que participa ativamente da construção da realidade social, que cria cultura, conhecimentos e saberes, que produz resistências.

Ao considerar que na escola pululam encontros de gerações, de sujeitos, práticas e culturas diversas, observo que experiências de autonomia e protagonismo das crianças podem acontecer nas salas de aula, nos pátios, nas bibliotecas. Concordo com Miguel Arroyo (2000), ao afirmar que mesmo diante dos processos de dominação ou subalternidade, há outra escola emergente nas rotinas cotidianas, nos problemas, na interação entre as pessoas, nas tensões presentes nas práticas educativas. Desse modo, "por maior que seja a desumanização que as estruturas sociais e politicas submetem a infância, [...] em todas as escolas encontramos surpresas." (ARROYO, 2000, p.137).

Então reflito: quantas surpresas podem acontecer nos momentos de contação de histórias? Quantas surpresas podem surgir no encontro adulto-criança quando os adultos se abrem para escutar as formas singulares de socialização, de organização de experiências, de produção de conhecimentos, de expressão do potencial criativo e poético, de resistências presentes na infância?

Impulsionada por essas questões e com desejo de fluir com as surpresas que podem acontecer, teci diálogos com diretoras escolares para abertura de tempo/espaço no qual Teia de Ananse pudesse ser realizada com as crianças em duas escolas de Ensino Fundamental, a saber: a Escola Municipal Joaquim de Ávila Neto da cidade de Coronel Fabriciano e a Escola Municipal Hilda Morais, localizada no distrito de Cachoeira Escura no município de Belo Oriente - MG.

$\mathrm{Na}$ cidade de Coronel Fabriciano, a Escola Municipal Joaquim de Ávila Neto está em um contexto urbano, no Bairro Nossa Senhora do Carmo, uma comunidade de periferia, próxima ao centro da cidade. A escola é rodeada por casas, igrejas,

SILVA, Sonaly Torres. Na teia de Ananse: performances de contação de histórias afro-brasileiras com crianças. Revista da FUNDARTE. Montenegro, p.01-23, ano 23, ํㅡ 42, julho/setembro de 2020. Disponível em: http://.seer.fundarte.rs.gov.br/index.php/RevistadaFundarte/index> 30 de setembro de 2020 


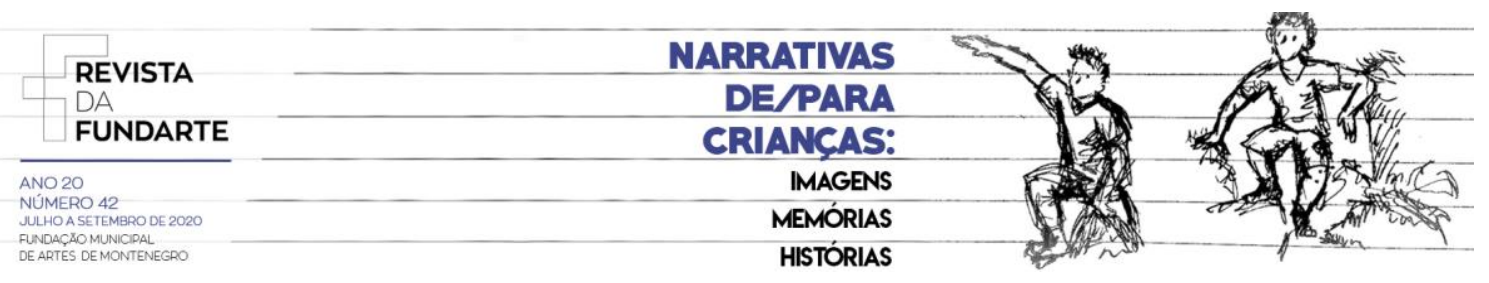

vendas, bares. Conforme dados informados pela diretora da escola, em 2018, no momento em que a pesquisa foi iniciada, a escola possuía 171 crianças no Ensino Fundamental, nível de ensino ao qual essa pesquisa se destinou.

Em Belo Oriente, o prédio da Escola Municipal Hilda Morais é uma construção nova, ao final de uma grande avenida. Não há casas ao lado, apenas estrada e uma área de plantação de eucalipto (matéria-prima para a fábrica de celulose da região). De acordo com informações disponibilizadas pela secretaria da escola, no ano de 2018, período em que a prática de pesquisa foi realizada, havia 482 crianças matriculadas no Ensino Fundamental - anos iniciais (1을 ao $5^{\circ}$ ano), no turno vespertino.
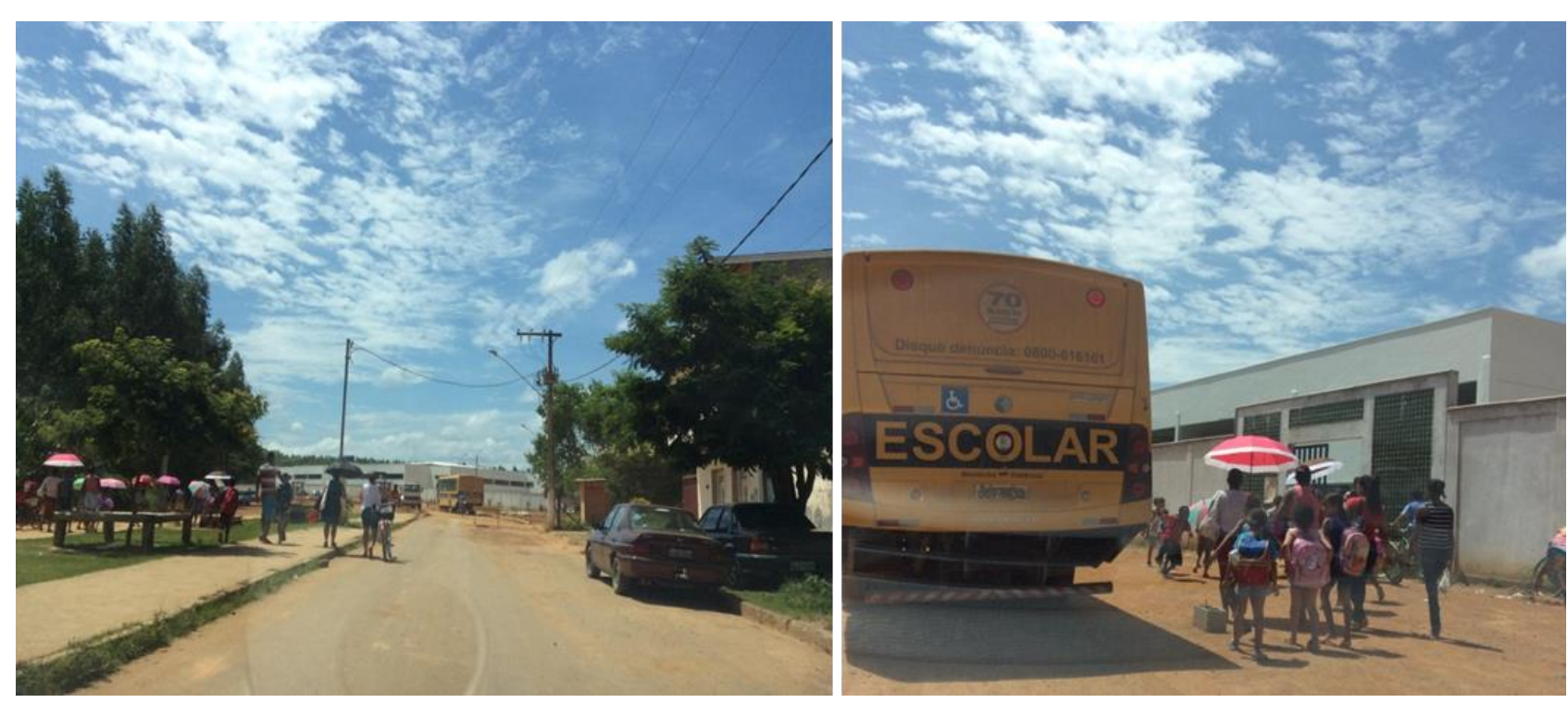

Ilustração 1: Chegança. À esquerda crianças e familiares a caminho da escola, na Av. Juscelino Kubitschek, Distrito de Cachoeira Escura, Belo Oriente/MG. À direita, a entrada da Escola Municipal Hilda Morais. 16 de março de 2018. (Fonte: Acervo da pesquisadora).

Trago essa imagem pois me tocou profundamente e suscitou diversas reflexões. Eu chegava nesta escola no início da tarde, junto com as crianças. Ficava encantada com esse momento: elas vinham de diferentes lugares, algumas acompanhadas de seus familiares, caminhando com sombrinhas para amenizar o calor do sol; outras em garupas de bicicletas; outras no ônibus escolar. Ao

SILVA, Sonaly Torres. Na teia de Ananse: performances de contação de histórias afro-brasileiras com crianças. Revista da FUNDARTE. Montenegro, p.01-23, ano 23, no 42, julho/setembro de 2020. Disponível em: http://.seer.fundarte.rs.gov.br/index.php/RevistadaFundarte/index> 30 de setembro de 2020 


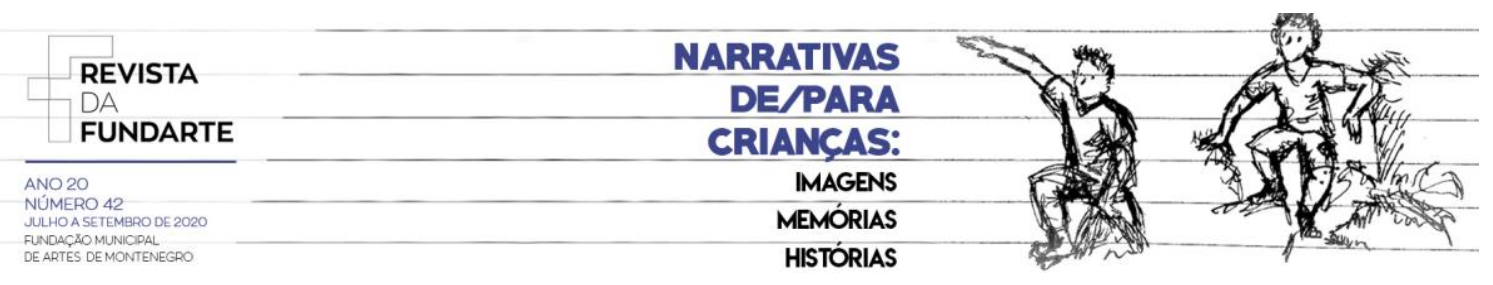

contemplar essa chegança reflito sobre a diversidade e dialogo com Juarez Dayrell (1999), para reiterar que a escola é um espaço sociocultural complexo, com sujeitos históricos reais, alunos (as) e professores (as), homens e mulheres, trabalhadores e trabalhadoras, negros (as) e brancos (as), adultos e crianças, oriundos de diferentes lugares, em relações dinâmicas de conflitos, negociações, em processos de reprodução, transformação e criação de práticas e saberes múltiplos.

No que tange às escolas nas quais a Teia de Ananse foi tecida, além de estar atenta às diferenças, considero importante também sinalizar alguns pontos em comum quanto às crianças que participaram da pesquisa: em sua maioria, elas são negras, pertencentes a grupos familiares de setores populares, muitas com condições precárias de vida e em vulnerabilidade social. Entretanto, neste movimento de conexão entre similitudes e diferenças, mesmo que seja possível identificar pontos comuns, ressalto que as crianças são plurais em relação às experiências cotidianas, às formas de apropriação e criação de saberes e culturas. Em diálogo com Sarmento (2005), concordo que elas são eminentemente multiculturais, pois, possuem modos distintos de simbolização do mundo, formulam diferentes interpretações dos outros, de si próprias, dos pensamentos, dos sentimentos, da sociedade.

Portanto, ao nos aproximarmos da criança, nós, professoras (es), pesquisadoras (es), contadoras (es) de histórias, devemos nos perguntar: quem é essa criança? De onde ele ou ela vem? Como vive? O que busca na escola? Como se expressa em seus grupos? Que legados culturais, recebeu e recebe de seus familiares, de seus ancestrais? Quais saberes e culturas vivenciam, inventam e constroem?

Refletir sobre essas questões é imprescindível porque, mesmo que não tenhamos todas as respostas, as perguntas podem funcionar no sentido de aguçar o olhar para percepção das diferenças. Podem nos ajudar a ampliar horizontes, para escutar as crianças, como sujeitos de múltiplas histórias.

SILVA, Sonaly Torres. Na teia de Ananse: performances de contação de histórias afro-brasileiras com crianças. Revista da FUNDARTE. Montenegro, p.01-23, ano 23, № 42, julho/setembro de 2020. Disponível em: http://.seer.fundarte.rs.gov.br/index.php/RevistadaFundarte/index> 30 de setembro de 2020 


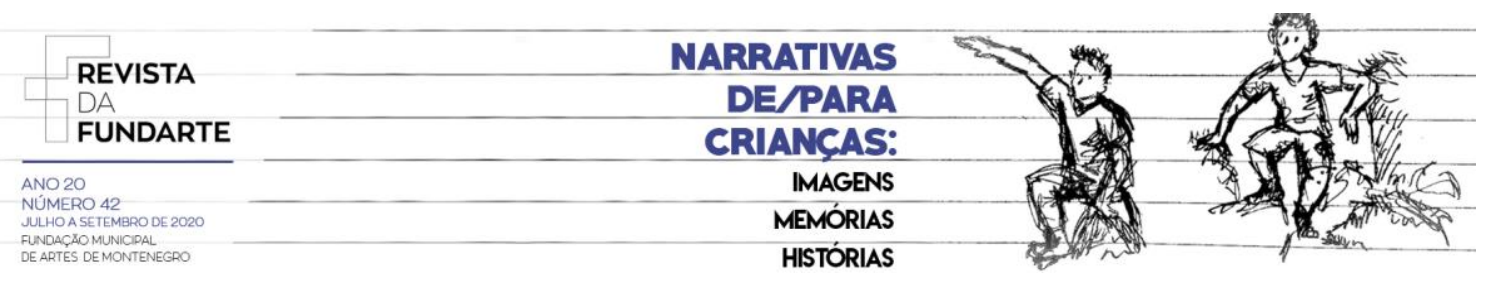

No processo desta pesquisa performativa um aspecto relevante foi a interação com as crianças, não apenas como interlocutoras, mas como coprodutoras de saberes e histórias.

\section{Como tudo começou? O que aconteceu?}

A pesquisa $\mathrm{Na}$ Teia de Ananse foi realizada no âmbito do Projeto Faz de Contos, uma ação educativo-cultural financiada por um edital de fomento à cultura. Esse projeto tinha como objetivo principal promover e potencializar a contação de histórias, com crianças em contextos escolares por meio das seguintes práticas: (i) performances de contação de histórias integrando contos africanos e expressões da capoeira. (ii) Oficinas de histórias com crianças. (iii) Oficinas de pintura de painéis com crianças. (iv) Criação de coletâneas - livros digitais contendo histórias africanas e histórias narradas pelas crianças. (v) Oficinas de capacitação com professoras. (vi) Evento final para lançamento da coletânea de histórias junto à comunidade escolar, com a presença dos familiares das crianças, coautoras da obra. Na imagem seguinte busco enfatizar os processos dinâmicos, as conexões e interdependência entre os diversos sujeitos e as várias ações realizadas nesse projeto.

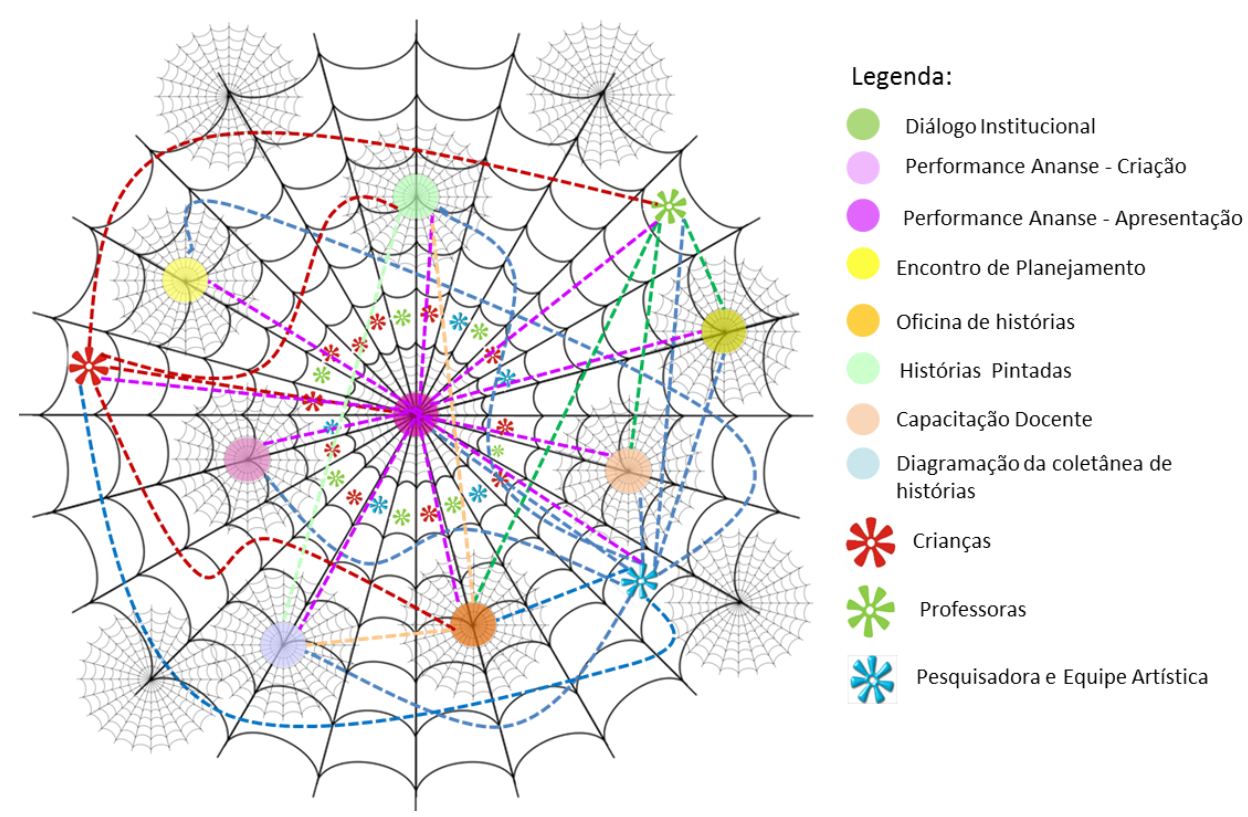

Ilustração 2: Faz de Contos - A Teia. Criação de Sonaly Torres. (Fonte: Acervo da pesquisadora).

SILVA, Sonaly Torres. Na teia de Ananse: performances de contação de histórias afro-brasileiras com crianças. Revista da FUNDARTE. Montenegro, p.01-23, ano 23, № 42, julho/setembro de 2020. Disponível em: http://.seer.fundarte.rs.gov.br/index.php/RevistadaFundarte/index> 30 de setembro de 2020 


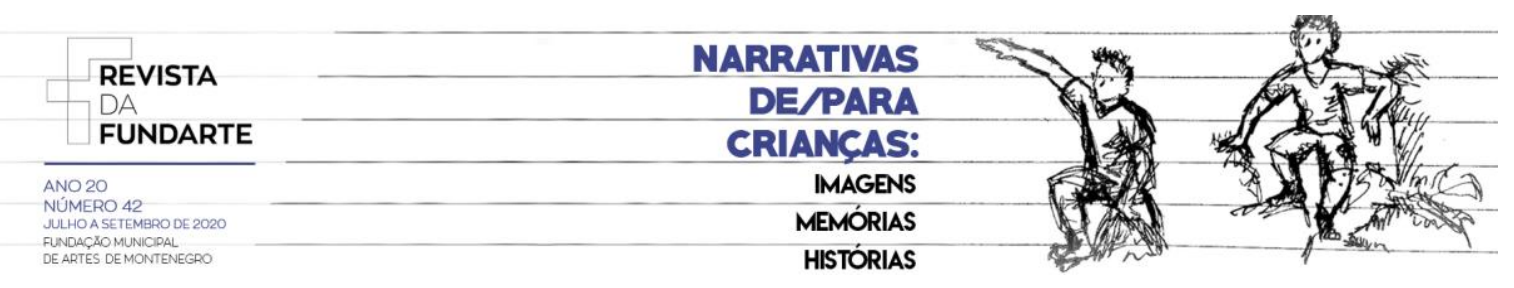

Ao analisar essa Teia é possível observar o quanto o Projeto Faz de Contos foi amplo, entretanto, para fins deste artigo, apenas duas práticas constituem experiências de descrição e análise: a Performance "Ananse" e a Oficina de Histórias "No Baú de Ananse".

\section{A Performance "Ananse"}

Abordar a contação de histórias como performance oportuniza compreendê-la como uma prática poética multissensorial, que envolve interações dinâmicas e simultâneas entre diversas potências corporais, sensoriais, espaço-temporais, para criar uma experiência expressiva e emotiva. Nessa perspectiva, o corpo, as diferentes formas de expressão, os processos de criação, interação e transformação têm primazia.

Foi por meio da apresentação da Performance "Ananse", criada e realizada por mim, juntamente com o amigo Roberto Yokel, que se deu o primeiro contato com as crianças no processo de pesquisa. Roberto é contador de histórias, ator, professor e estudioso da cultura africana e afro-brasileira. Nós integramos o coletivo Rizoma Cultural, criado em 2002, na cidade de Coronel Fabriciano. Desde então, atuamos juntos.

A criação e preparação dessa performance envolveu estudos e leitura dramática de histórias, jogos e brincadeiras com cantigas e ritmos afro-brasileiros, exercícios de capoeira, ensaios, confecção de cenários e figurinos. A performance tomou forma com entrelaçamento de contos africanos, brincadeiras cantadas e expressões afro-brasileiras do universo da Capoeira e do Cacuriá. Sua apresentação foi realizada nas escolas tendo como espectadores todas as crianças e professoras do turno em que a pesquisa foi desenvolvida, a saber: o turno matutino na Escola Joaquim de Ávila Neto e o vespertino na escola Hilda de Morais. Ao todo aconteceram 11 apresentações, em diferentes momentos da pesquisa, tendo como espectadores um total de 659 crianças e 86 adultos.

SILVA, Sonaly Torres. Na teia de Ananse: performances de contação de histórias afro-brasileiras com crianças. Revista da FUNDARTE. Montenegro, p.01-23, ano 23, no 42, julho/setembro de 2020. Disponível em: http://.seer.fundarte.rs.gov.br/index.php/RevistadaFundarte/index> 30 de setembro de 2020 


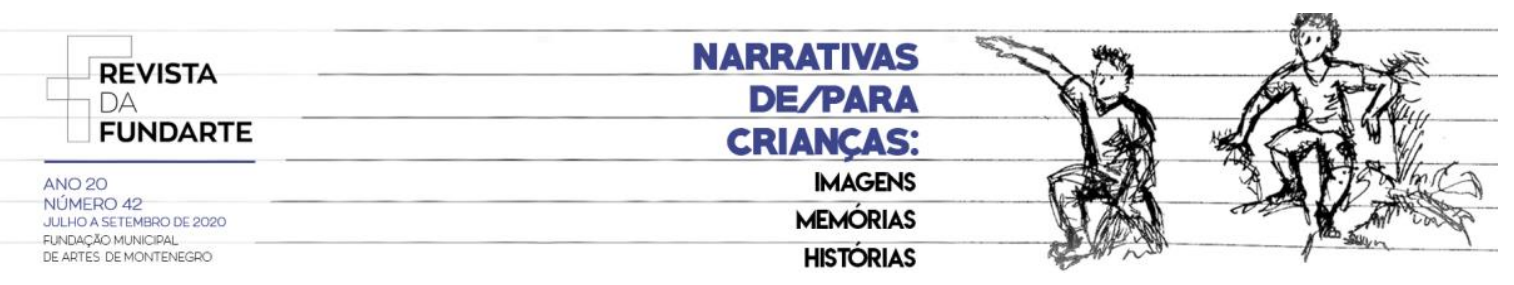

A interação com o público no decorrer das apresentações gerou diversas transformações na performance, como por exemplo a variação de contos africanos a serem narrados conforme escolha das crianças, como também a criação e inclusão de brincadeiras cantadas sugeridas por elas.

A performance "Ananse" foi o elemento propulsor para tecer a teia com as demais atividades de pesquisa. Desse modo, após as apresentações eram realizadas as oficinas de histórias.

\section{A Oficina de Histórias - No Baú de Ananse}

A outra prática realizada junto às crianças nesta Teia de Ananse é a Oficina de Histórias. Desenvolvida por mim, em parceria com Roberto Yokel e com a artista plástica Ângela Ataíde, essa oficina teve como principal objetivo escutar as crianças e suas histórias. Diferentemente da apresentação da performance, essa atividade era destinada a um número menor de crianças. Portanto, foi necessário selecionar, em cada escola, uma turma específica para participar.

Recordo que, em se tratando de contexto escolar, nosso contato com as crianças foi mediado pelas definições dos adultos educadores que governam a organização do tempo e espaço das atividades desenvolvidas na escola. Desse modo, em diálogo as diretoras das escolas parceiras, na Escola Municipal Joaquim de Ávila Neto, foi selecionada a turma do $4^{\circ}$ ano e na Escola Municipal Hilda Morais as atividades foram realizadas em uma turma do $3^{0}$ ano, ambas do Ensino Fundamental.

Após a definição das turmas, emergiu uma questão referente ao número de crianças participantes. O planejamento inicial da oficina previa a participação de quinze crianças, em cada escola, porém, como eleger quinze em turmas com aproximadamente trinta crianças? Quais seriam os critérios para selecionar quais participariam? Roberto Yokel nos alertou que o problema não era um critério de seleção, mas: qual seria o critério de exclusão das crianças que não participariam?

SILVA, Sonaly Torres. Na teia de Ananse: performances de contação de histórias afro-brasileiras com crianças. Revista da FUNDARTE. Montenegro, p.01-23, ano 23, № 42, julho/setembro de 2020. Disponível em: http://.seer.fundarte.rs.gov.br/index.php/RevistadaFundarte/index> 30 de setembro de 2020 


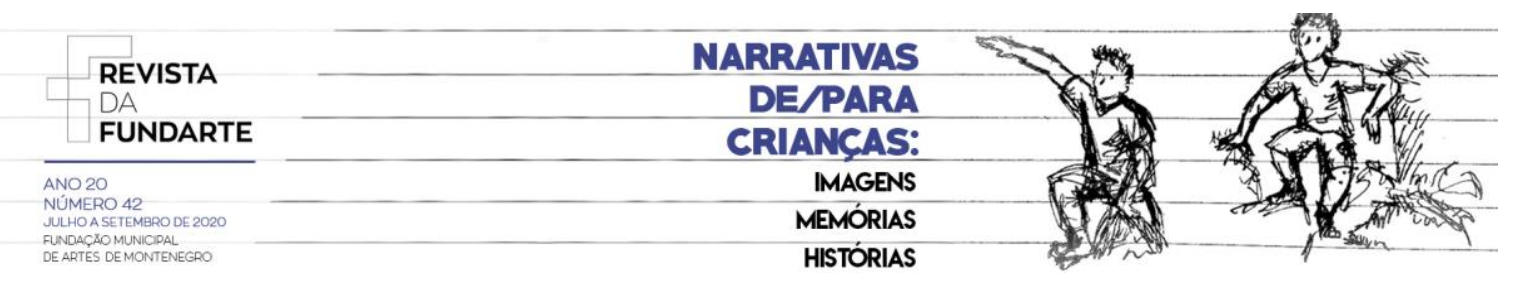

Diante dessa problemática alteramos a proposta inicial e as oficinas foram realizadas com todas as crianças da turma selecionada em cada escola.

Dessa forma foi constituído o grupo de crianças com as quais dialogamos na Oficina de Histórias, sendo que: na Escola Municipal Hilda Morais a oficina foi realizada no turno vespertino, com vinte e seis crianças, com idade entre oito e onze anos de idade. Na Escola Municipal Joaquim de Ávila Neto foi realizada no turno matutino, com trinta crianças que tinham entre nove e dez anos.

Quanto à metodologia da oficina de histórias No Baú de Ananse, as atividades envolveram três movimentos: (i) brincante; (ii) escutar-narrar; (iii) revisão das histórias. Uso o termo movimentos e não etapas, pois, apesar das atividades serem apresentadas neste texto de forma sequencial, na prática são totalmente interligadas e entrelaçadas de forma não-linear.

\section{Movimento Brincante}

O Movimento Brincante acontecia imprescindivelmente no início da oficina, mas também poderia emergir no decorrer ou no final, conforme o fluxo das práticas. As crianças participavam diretamente da escolha e prática das atividades: seguíamos o pulsar dos corpos, o fluir do grupo, para propor jogos teatrais, atividades corporais lúdicas; ritmos, brincadeiras cantadas. As atividades corporais e jogos teatrais eram propostos a partir das abordagens do Teatro do Oprimido, da Dinâmica Energética do Psiquismo e da Capoeira.

Tais abordagens foram selecionadas por serem potentes em minha trajetória de vida e por influenciarem diretamente a forma como eu conto histórias, a maneira como me relaciono com o mundo e com as crianças. Em diálogo com as palavras da contadora de histórias Regina Machado (2015), observo que essas práticas integram o meu baú de recursos internos que reanimam minha capacidade de brincar, ampliam a flexibilidade perceptiva, a capacidade para criar, para dar vida às performances de contação de histórias. A seguir descrevo essas três abordagens e a forma como estiveram presentes na Oficina de Histórias. 


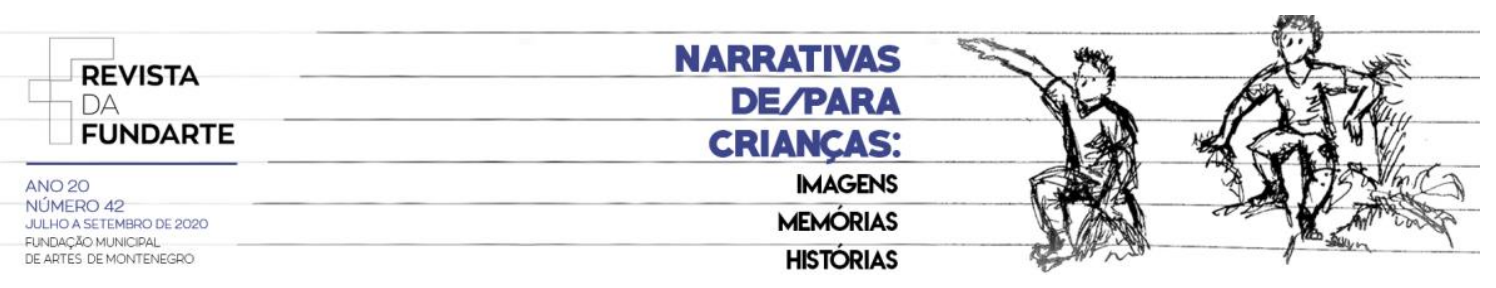

A poética do Teatro do Oprimido criada pelo teatrólogo Augusto Boal a partir de 1973, envolve uma nova estética, um novo fazer teatral como uma prática horizontal, democrática, dialógica e contextualizada. Na Teia de Ananse, por meio das práticas de Teatro do Oprimido, buscávamos propiciar o protagonismo das crianças no contexto escolar com abertura de espaços para "transformar o espectador, ser passivo no fenômeno teatral, em sujeito, em ator, em transformador da ação dramática" (BOAL, 1991. p. 138). Assim, liberado do lugar de espectador, o sujeito atua, se lança na ação, cria o diferente, re-cria e transforma a cena. No caso desta pesquisa, cria, recria e transforma suas histórias.

No período de 1990 a 1992 fui aluna do Boal e, em diferentes situações como oficinas e experiências de teatro-fórum pude escutá-lo dizer: quando entramos em cena, assumindo o protagonismo no teatro, passamos também a entrar em cena e a assumir o protagonismo na vida. Portanto, ao aprender com Boal e re-conhecer em minha história, em meu corpo, as transformações a partir da poética do Teatro do Oprimido, penso-sinto que essa experiência é imensamente potente para criação de práticas que favoreçam a inversão nos jogos de poder e opressão na relação adultocriança. A partir dessas experiências e estudos, foram integradas à Teia de Ananse práticas de Teatro do Oprimido, no intuito contribuir para a criança se deslocar do lugar de espectadora e atuar como atriz/ator principal.

De acordo com Boal (1991), o plano geral de transformação do espectador em ator pode ser sistematizado em quatro etapas. Dentre essas, vivenciamos duas na Teia de Ananse: (i) conhecimento do corpo com exercícios para escutar suas sensações, tensões, limitações e possibilidades de liberação; (ii) tornar o corpo expressivo, com práticas cujo intento era abandonar formas de expressão usuais e cotidianas, incluindo novas formas de expressão e movimentos. Nesse sentido, foram realizados junto às crianças os seguintes jogos do Teatro do Oprimido: hipnotismo, ninguém com ninguém, transformando o nada, imagem da palavra. Além disso, como práticas que potencializavam a escuta do corpo e a pujança corporal, realizamos brincadeiras cantadas relacionadas à capoeira e outras expressões afrobrasileiras, como também exercícios da Dinâmica Energética do Psiquismo - DEP.

SILVA, Sonaly Torres. Na teia de Ananse: performances de contação de histórias afro-brasileiras com crianças. Revista da FUNDARTE. Montenegro, p.01-23, ano 23, no 42, julho/setembro de 2020. Disponível em: http://.seer.fundarte.rs.gov.br/index.php/RevistadaFundarte/index> 30 de setembro de 2020 


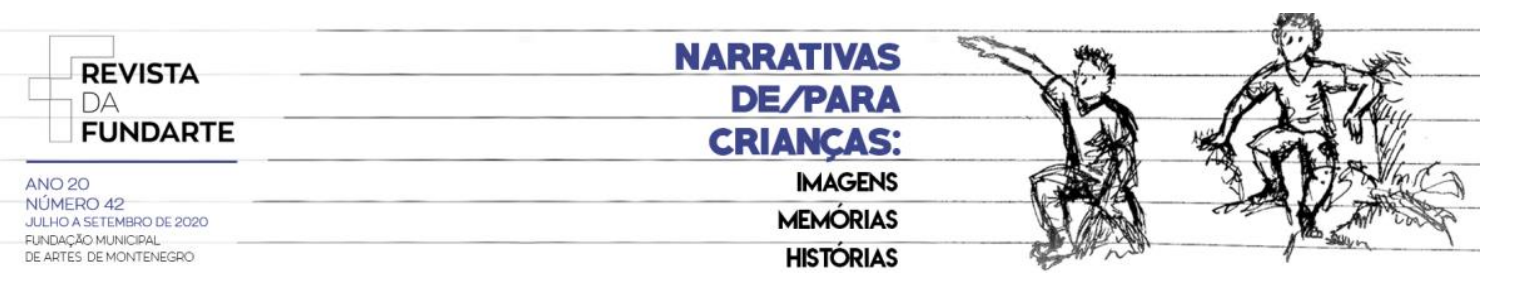

Conheci a DEP em processos de formação no universo terapêutico, no período de 2015 a 2017. Desde então, as práticas dessa abordagem são significativas para mim, principalmente em relação aos processos corporais, que propiciam autopercepção, movimento e transformação. A DEP é uma escola iniciática, um caminho de autoconhecimento e de desenvolvimento pessoal, criada pelas psicólogas Theda Basso e Aidda Pustilnik. Fundamentando-se em saberes da ciência ocidental e das tradições sagradas do oriente e do ocidente, essa escola tem como um de seus pressupostos o entendimento de que nós, seres humanos, somos múltiplas manifestações do Todo, somos consciência corporificada, sendo que consciência é o Ser na Totalidade, presente no corpo: no corpo está o Deus invisível. Desse modo, na posse de sua vitalidade, o ser humano, "é um ser que flui, que é flexível, que reorganiza suas experiências no presente" (BASSO; PULSTILNIK, 2002, p. 20).

Assim sendo, a DEP propõe recursos metodológicos e técnicos cujo foco principal é propiciar o desbloqueio de núcleos de energia no corpo, de modo a favorecer maior fluidez, flexibilidade e expansão das potências do ser, com emergência de um estado de presença. Penso que tais características são fundamentais aos contadores de histórias nessa Teia de Ananse, pois a experiência de presença nos possibilita escutar e dialogar com as crianças em um encontro de seres cujos corpos são múltiplos e infinitos em suas possibilidades criativas. Nessa direção foram realizados os seguintes exercícios ligados à DEP: práticas de respiração em diferentes modalidades, percepção das sensações do/no corpo, escuta ampliada. Com eles buscávamos criar momentos de silêncio, contribuir para ampliar a capacidade de escuta e propiciar maior fluidez e flexibilidade dos corpos na experiência de contação de histórias.

Contudo, a prática que oportunizou de forma mais potente a fluidez e ludicidade no Movimento Brincante da Oficina de Histórias foi a Capoeira. Concordo plenamente e faço coro com Mestre Môa, ao cantar que:

SILVA, Sonaly Torres. Na teia de Ananse: performances de contação de histórias afro-brasileiras com crianças. Revista da FUNDARTE. Montenegro, p.01-23, ano 23, no 42, julho/setembro de 2020. Disponível em: http://.seer.fundarte.rs.gov.br/index.php/RevistadaFundarte/index> 30 de setembro de 2020 


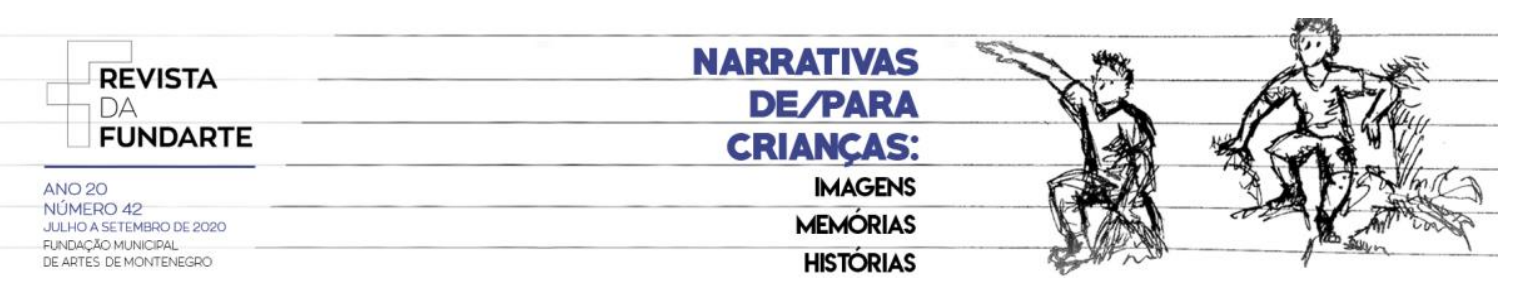

Capoeira tem história fundamentada em segredos. Quando parece tá séria, ela não passa de brinquedo. Nela não se aprende tudo, mas se ganha habilidade. Quanto mais você pratica mais conhece a liberdade. (MESTRE MOA DO KATENDÊ, 2003).

Minha experiência com a capoeira aconteceu na Associação de Capoeira Lenço de Seda. Foi um exercício de liberdade e alegria, que ainda hoje estão presentes em meu corpo, emoções e conhecimentos. A partir dos saberes dos mestres e da prática vivenciada nas rodas, penso-sinto que a capoeira é simultaneamente fluidez, movimento, jogo, luta, ritmo, dança, histórias, brincadeira.

No período entre 2004 e 2008 essa prática foi intensificada em minha trajetória, quando desenvolvi no Mestrado em Psicologia um estudo sobre a capoeira e os processos de subjetivação, que originou a dissertação "Capoeira: movimento e malícia em jogos de poder e resistência" (SILVA, 2007). Nessa obra abordo a capoeira como uma experiência afro-brasileira de resistência, que integra diferentes dimensões e potencializa a criação de novas formas de viver, com invenção de espaços de liberdade. Observo que a capoeira "se configura como um espaço-tempo que abre campos de possibilidades, processos de invenção" nos quais predominam outras temporalidades, outras formas de transmissão de saberes, de conceber o divino, outros modos de ser e estar no mundo (SILVA, 2007, p. 17).

$\mathrm{Na}$ Teia de Ananse a capoeira esteve presente por meio dos movimentos da ginga, dos ritmos, das ladainhas e corridos de autoria dos mestres João Grande, João Pequeno, Moa do Katendê e Reginaldo Véio. Essas músicas, que expressam saberes dos mestres, integram meu baú de recursos internos como preciosas histórias cantadas, que são reinventadas quando compartilhadas no encontro com as crianças.

Desse modo, no Movimento Brincante a integração entre práticas da Capoeira, do Teatro do Oprimido e da DEP funcionaram como elementos propulsores da potência corporal, da liberdade e dos jogos lúdicos presentes nos processos de criar e de compartilhar histórias. Além disso, os fundamentos dessas abordagens foram basilares para a nossa atuação (Eu, Roberto Yokel e Ângela

SILVA, Sonaly Torres. Na teia de Ananse: performances de contação de histórias afro-brasileiras com crianças. Revista da FUNDARTE. Montenegro, p.01-23, ano 23, № 42, julho/setembro de 2020. Disponível em: http://.seer.fundarte.rs.gov.br/index.php/RevistadaFundarte/index> 30 de setembro de 2020 


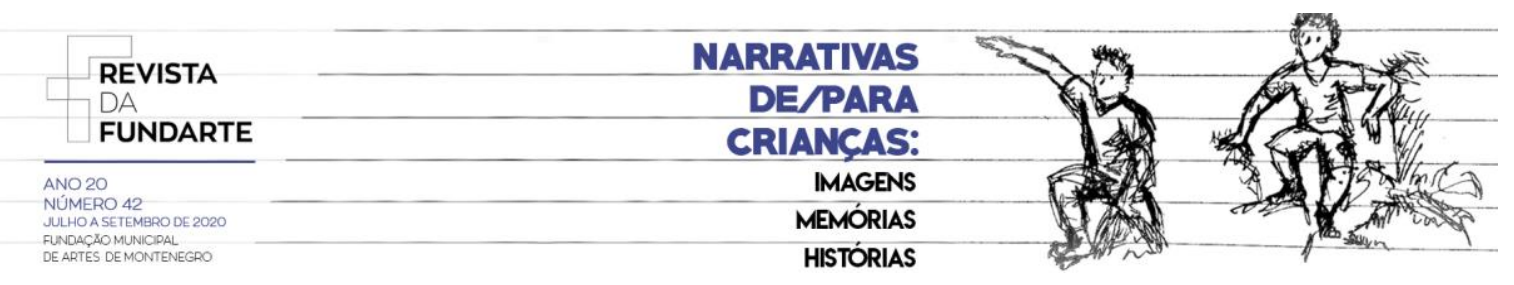

Ataíde) na Oficina de Histórias, pois, inspirados no teatro do oprimido buscávamos atuar de forma flexível, abrindo espaço para as crianças transitarem de espectadores em espect-atores que co-criavam o roteiro da oficina. Com as ferramentas da DEP, buscávamos potencializar a presença viva, atenta e consciente da energia fluindo livremente pelo corpo, no encontro com as crianças e suas histórias. Com o universo da capoeira procurávamos estar livres para gingar, jogar, brincar, com os mecanismos de poder-saber, produzindo resistências. Pois, de acordo com o Mestre Reginaldo Véio na capoeiragem predominam a ludicidade, a brincadeira, a alegria de experimentar o corpo com liberdade de movimento em conexão com o ritmo, com outros corpos, em uma manifestação festeira (REGINALDO VÉIO apud SILVA, 2007).

Assim, a Oficina de Histórias No Baú de Ananse era iniciada com a manifestação festeira do Movimento Brincante, cujo objetivo era soltar o corpo, movimentar, interagir, cantar, dançar, brincar, como práticas de abertura para as histórias.

\section{Movimento Escutar-Narrar}

Em sintonia com o Movimento Brincante acontecia o Movimento Escutarnarrar que não se referia apenas a escutar o outro, mas convidava as crianças a aprofundarem a escuta de si mesmas, seus corpos, suas histórias e escolherem uma para contar aos colegas. Esse movimento foi desenvolvido em três momentos. O primeiro consistia em silenciar: a partir de dinâmicas da DEP, com práticas de respiração e escuta do coração, as crianças eram convidadas a sentir o corpo, as emoções, a própria respiração. Assim, criávamos uma ambiência de silêncio e experimentávamos uma nova forma de lidar com o tempo (diferente dos enquadramentos dos horários escolares), com as quais respeitávamos coletivamente o tempo singular da respiração e do pulsar do coração de cada criança.

SILVA, Sonaly Torres. Na teia de Ananse: performances de contação de histórias afro-brasileiras com crianças. Revista da FUNDARTE. Montenegro, p.01-23, ano 23, № 42, julho/setembro de 2020. Disponível em: http://.seer.fundarte.rs.gov.br/index.php/RevistadaFundarte/index> 30 de setembro de 2020 


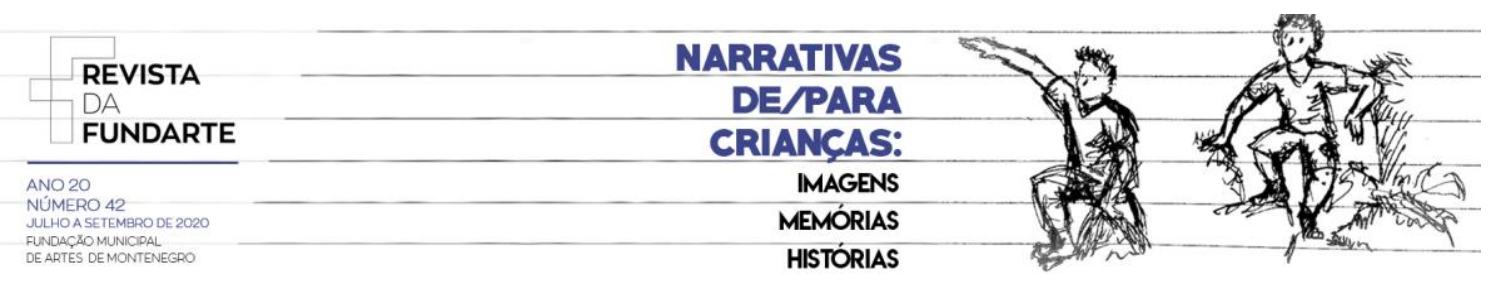

Após esse momento de silenciar, iniciávamos o momento recordar/desenhar. A palavra recordar vem do latim: cordis é coração; re-cordis é passar novamente pelo coração. Assim, conforme eu escrevi, juntamente com Maria do Rosário, na obra "Faz de Contos: as crianças, os contos e o contar", recordar e narrar histórias abre um tempo singular, em que passamos pelo coração e podemos reviver sensações, emoções, saberes e sabores, fluindo com a imaginação (RODRIGUES; SILVA, 2016). Nesse sentido, cada criança podia buscar uma posição confortável quem quisesse poderia deitar, mudar de lugar, fechar os olhos para recordar uma história que gostava. Nesse processo, pausadamente eram verbalizadas por mim questões como: você se recorda de uma história que gosta muito? Que história é essa? Quem é a pessoa que contou essa história para você? Quais as imagens você vê ao recordar esse momento? Quais os sentimentos, os cheiros, sabores e sons dessa história? Como seria contar essa história?

Enquanto eu apresentava as questões no intuito de contribuir com o ato de recordar, Ângela Ataíde e Roberto Yokel distribuíam papel, giz de cera e canetinhas coloridas, ao alcance das crianças. Cada criança em seu tempo, quando já tivesse escolhido a história, era convidada a fazer um desenho livre como expressão dessa história que desejava narrar.

Nesse processo a crianças se posicionam livremente na sala de aula. Rompendo a configuração de carteiras enfileiradas ou da roda, os corpos ocupavam os espaços com liberdade para criar com os materiais disponíveis. A artista plástica Ângela Ataíde acompanhava esse momento no qual, por meio do desenho livre, as crianças expressavam cenas, personagens ou qualquer outra imagem relativa à história que recordou. Ao final, fazíamos novamente uma roda na qual cada criança podia compartilhar com toda turma o seu desenho, juntamente com o título da história escolhida.

Após recordar/desenhar, era realizado o terceiro momento escutar-narrar, no qual as histórias eram contadas em pequenos grupos cuja formação associou dois critérios: a similitude dos desenhos/temáticas das narrativas e a escolha das crianças, com diálogos e negociações coletivas. A forma de narrar e a ordem de

SILVA, Sonaly Torres. Na teia de Ananse: performances de contação de histórias afro-brasileiras com crianças. Revista da FUNDARTE. Montenegro, p.01-23, ano 23, № 42, julho/setembro de 2020. Disponível em: http://.seer.fundarte.rs.gov.br/index.php/RevistadaFundarte/index> 30 de setembro de 2020 


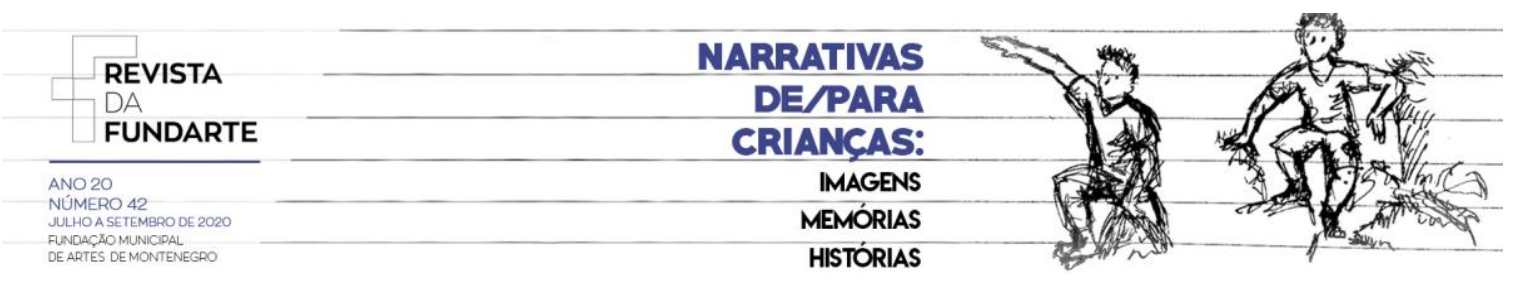

apresentação de cada narrativa também eram definidos coletivamente pelas crianças, em cada grupo. As histórias narradas nos grupos foram gravadas por mim, pelo contador de histórias Roberto Yokel e pela artista plástica Ângela Ataíde. Posteriormente foram transcritas por mim. Após a transcrição houve a revisão dos textos junto às crianças no movimento Revisão das Histórias.

\section{Movimento Revisão das histórias}

Esse movimento foi realizado por mim em encontros individuais com cada criança. As narrativas transcritas eram apresentadas para as crianças autoras fazerem a leitura. Então se iniciava um processo de reflexão acerca da narrativa escrita. Dialogicamente eu e a criança fazíamos a leitura da história. Eu propunha algumas questões referentes ao texto. Analisávamos o texto, refletíamos sobre as diferenças entre o texto narrado e escrito. A criança observava, argumentava e escolhia as alterações a serem feitas. A palavra final era sempre a da criança.

Após o Movimento Revisão das Histórias, as histórias narradas pelas cinquenta e seis crianças que participaram da oficina foram publicadas em dois livros digitais.
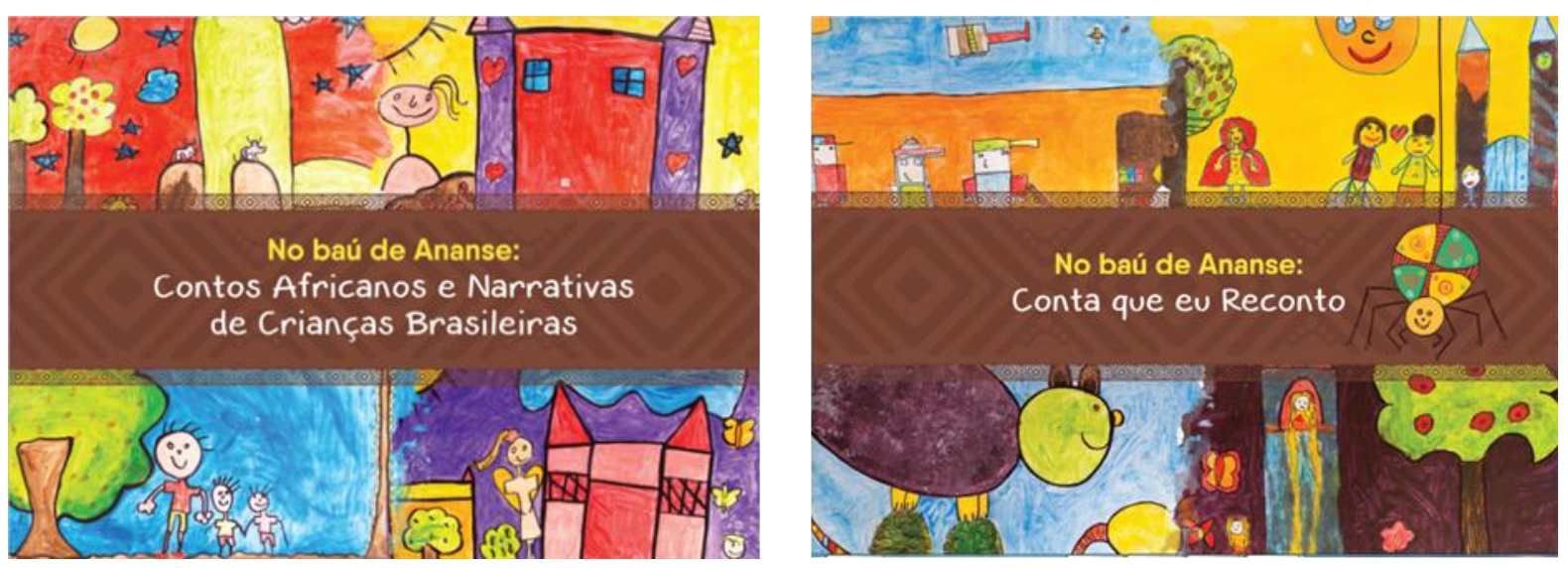

Ilustração 3:No Baú de Ananse. Capas dos livros digitais, com inclusão de painéis pintados pelas crianças que participaram da Oficina de Histórias. Criação de Hudson Sales. (Fonte: acervo da pesquisadora).

SILVA, Sonaly Torres. Na teia de Ananse: performances de contação de histórias afro-brasileiras com crianças. Revista da FUNDARTE. Montenegro, p.01-23, ano 23, № 42, julho/setembro de 2020. Disponível em: http://.seer.fundarte.rs.gov.br/index.php/RevistadaFundarte/index> 30 de setembro de 2020 


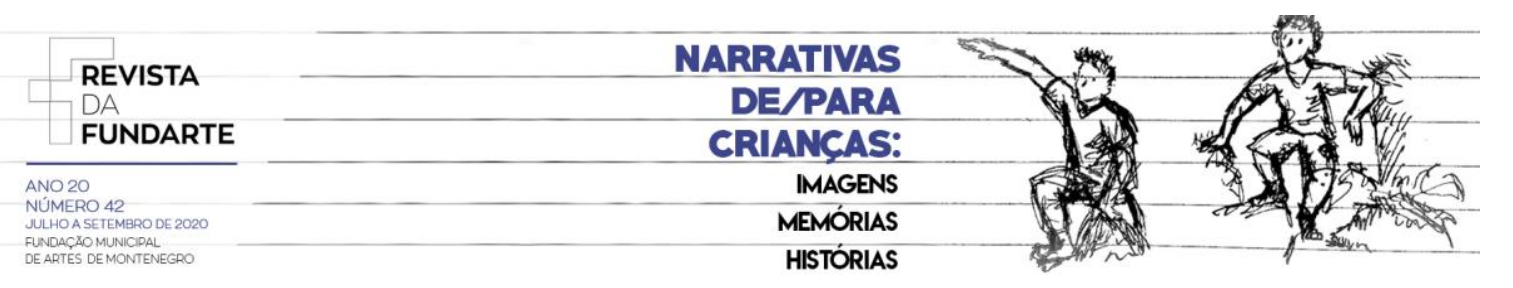

Por fim, enfatizo que, em todos os movimentos da Oficina de Histórias na Teia de Ananse buscávamos criar oportunidades para o protagonismo das crianças: a escolha das atividades na oficina era sempre realizada escutando-as. Além disso, em todo processo buscávamos observar o tipo de intervenção que a experiência da Teia de Ananse proporcionou, auxiliou ou impediu no encontro com as crianças. Nesse sentido, a Oficina funcionava como um roteiro aberto, que adquiriu configurações singulares em cada grupo.

\section{Considerações Finais}

Este artigo configura-se como um exercício analítico que tenho feito durante minha pesquisa de doutorado. Em suma, a pesquisa $\mathrm{Na}$ Teia de Ananse acontece por meio da integração de diferentes práticas de contação de histórias com crianças.

Ao apresentar a Performance "Ananse" busquei uma aproximação sensível, curiosa e poética com as crianças, em interação com suas diferentes formas de criação e invenção. Entretanto, mais importante que contar histórias para as crianças, é ouvir suas histórias. Escutar as crianças propicia compreender não apenas suas narrativas, como também as formas como elas agem e interpretam o mundo. Concordo com Luciana Hartmann (2017) quando afirmar que as vozes das crianças podem nos ensinar muito sobre os processos de socialização, de organização de suas experiências, pois, em interação com os pares e com os adultos, as crianças estão produzindo cultura, constituindo modos de viver, de se relacionar, de se expressar, inclusive (ou principalmente) por meio de suas narrativas.

Além disso, cada momento de contação é único, imediato: a maneira de contar, os sentimentos, a forma de interação adulto-crianças e crianças-crianças, não se repetem. Penso ser essa uma das qualidades mais potentes da contação de histórias na perspectiva das performances, bem como desta pesquisa performativa: a abertura para diferentes maneiras de ver o mundo, de criar novos significados por

SILVA, Sonaly Torres. Na teia de Ananse: performances de contação de histórias afro-brasileiras com crianças. Revista da FUNDARTE. Montenegro, p.01-23, ano 23, no 42, julho/setembro de 2020. Disponível em: http://.seer.fundarte.rs.gov.br/index.php/RevistadaFundarte/index> 30 de setembro de 2020 


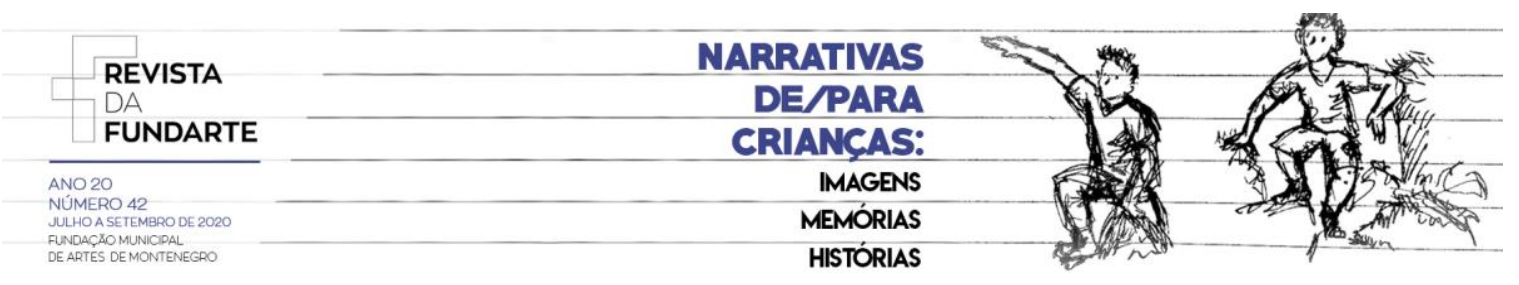

meio de práticas poéticas nas quais a potência do corpo, os processos de criação, interação e transformação têm primazia.

Desse modo, ao partilhar essas experiências neste texto procuro abrir novos diálogos, como um convite para que você, leitora, leitor, também se aventure no universo das performances de contação de histórias, tendo como prioridade a escuta das histórias das crianças. Em diálogo com elas podemos aprender muito sobre suas práticas, seus conhecimentos, suas experiências criativas e poéticas como formas de resistências.

Entrou pelo pé do pinto, saiu pelo pé do pato. Eu contei uma, você que conte quatro!

\section{Referências:}

ADICHIE, C. N. Os perigos de uma história única. Oxford: Conference Annual Tecnology, Entertainment and Design - Ted Global, 2009. Disponível em https://www.geledes.org.br/chimamanda-adichie-o-perigo-de-uma-unica-historia/

ANDRADE, Carlos Drummond de. Antologia poética. Rio de Janeiro: Record, 2001.

ARENA, D; LOPES, N. PNBE 2010: personagens negros como protagonistas. Educação e Realidade. Porto Alegre, v. 38, n. 4, p. 1147-1173, 2013.

ARROYO, M. G. Ofício de Mestre: imagens e autoimagens. Petrópolis: Vozes, 2000.

BADOE, Adwoa; DIAKITE, Baba Wagué. Histórias de Ananse. São Paulo: Edições SM, 2006.

BASSO, T.; PUSTILNIK, A. Corporificando a Consciência: teoria e prática da Dinâmica Energética do Psiquismo. São Paulo: Instituto Cultural Dinâmica Energética do Psiquismo.

BAUMAN, R. Fundamentos da performance. Sociedade e Estado, Brasília, v. 29, n. 3, p. 727-746, 2014.

BOAL, A. Teatro do Oprimido e outras poéticas politicas. Rio de Janeiro: Civilização Brasileira S.A, 1991.

SILVA, Sonaly Torres. Na teia de Ananse: performances de contação de histórias afro-brasileiras com crianças. Revista da FUNDARTE. Montenegro, p.01-23, ano 23, № 42, julho/setembro de 2020. Disponível em: http://.seer.fundarte.rs.gov.br/index.php/RevistadaFundarte/index> 30 de setembro de 2020 


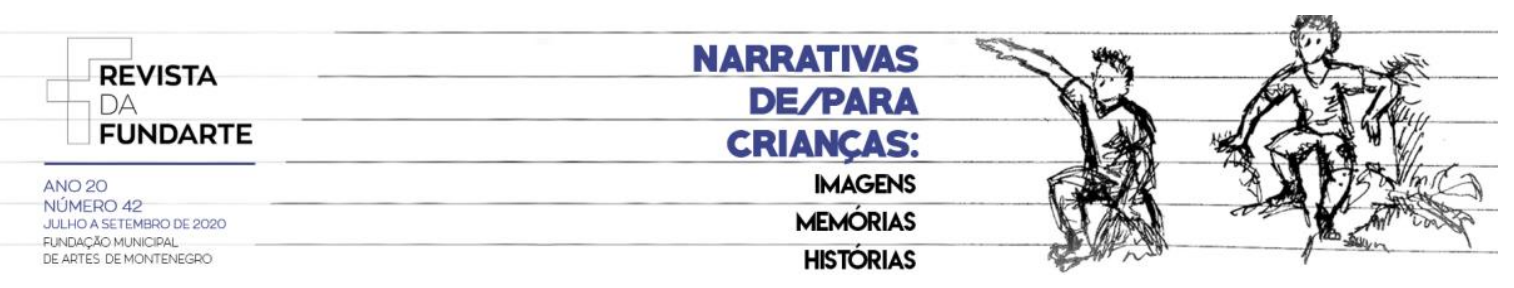

DAYRELL, J. A escola como espaço sociocultural. In: DAYRELL, J. (Org.) Múltiplos olhares sobre educação e cultura. Belo Horizonte: Editora da UFMG, 1999.

GIRARDELLO, G. Uma clareira no bosque: Contar histórias na escola. Campinas: Papirus, 2014.

HAMPATE BÂ, A. A tradição viva. In: KI-ZERBO, J. (Org.) História Geral da África. São Paulo: Ed. Ática/UNESCO, 1980.

HARTMANN, L. Desafios da diversidade em sala de aula: um estudo sobre performances narrativas de crianças imigrantes. Cadernos CEDES. Campinas, v. 37, n. 101, p. 45-64, 2017.

HARTMANN, L. Arte e a Ciência de contar histórias: como a noção de performance pode provocar diálogos entre a pesquisa e a prática. Moringa. João Pessoa, V. 5 N. 2 Jul-dez, 2014.

HASEMAN, B. Manifesto pela Pesquisa Performativa. In: SILVA, Charles R.; FELIX, Daina; et al (orgs). Resumos do 5o Seminário de Pesquisas em Andamento PPGAC/USP. São Paulo: PPGAC-ECA/USP, p. 41-53, 2015.

MACHADO, R. A arte da palavra e da escuta. São Paulo: Editora Reviravolta, 2015.

MESTRE MOA DO KATENDÊ. In: Antologia de ladainhas e corridos. Timóteo: Gravadora Sonopress, CD.2003.

RODRIGUES, M. R. F.; SILVA, S. T. Faz de contos: as crianças, os contos e o contar. Ipatinga: Edição das autoras, 2016.

SARMENTO, M. J. Gerações e alteridade: interrogações a partir da sociologia da infância. Educação e Sociedade. Campinas, v. 26, n. 91, p.361-378, 2005.

SILVA, A. C. A representação social do negro no livro didático: O que mudou? Por que mudou? Salvador: EDUFBA, 2011.

SILVA, E. F. Por uma educação para as relações étnico-raciais: entre desafios e possibilidades. In: OLIVEIRA, A.; SILVA, M.; AIRES, J. (Orgs.) Nas confluências do Axé: Refletindo os desafios e possibilidades de uma educação para as relações étnico-raciais. João Pessoa: Editora do CCTA, 2015.

SILVA, S. T. Capoeira: movimento e malícia em jogos de poder e resistência. (Mestrado em Psicologia) - Pontifícia Universidade Católica de Minas Gerais, Belo Horizonte, 2007.

ZUMTHOR, P. Performance, recepção, leitura. São Paulo: Cosac Naify, 2002.

SILVA, Sonaly Torres. Na teia de Ananse: performances de contação de histórias afro-brasileiras com crianças. Revista da FUNDARTE. Montenegro, p.01-23, ano 23, № 42, julho/setembro de 2020. Disponível em: http://.seer.fundarte.rs.gov.br/index.php/RevistadaFundarte/index> 30 de setembro de 2020 